\title{
Strategi UMKM untuk Meningkatkan Perekonomian selama Pandemi Covid-19 pada saat New Normal
}

\section{Fadilah Nur Azizah ${ }^{1}$, Igo Fadilah Ilham ${ }^{2}$, Liza Putri Aqidah ${ }^{3}$, Safira Aliyani Firdaus ${ }^{4}$, Setyani Agung Dwi Astuti ${ }^{5}$, Imam Buchori ${ }^{6}$}

Univarsitas Islam Negeri Sunan Ampel Surabaya

Email: fadilahnurazizah59@gmail.com, igofadilahilham1@gmail.com, putriliza035@gmail.com, safirafirdaus06@gmail.com, setyaniagung@gmail.com ibe@uinsby.ac.id

\begin{tabular}{l}
\hline Article Info \\
\hline Article history: \\
Published: Dec 25,2020 \\
Page: $46-62$ \\
\hline
\end{tabular}

Keyword:

Covid-19, MSMEs, Impact, Strategy

\begin{abstract}
Penelitian ini bertujuan untuk mengetahui dan menganalisis strategi untuk meningkatkan perekonomian UMKM pada saat new normal diterapkan akibat adanya dampak dari pandemi Covid19. Metode penelitian yang digunakan yaitu metode kulitatif deskriptif, Hasil yang diperoleh dari penelitian ini menunjukkan bahwa perlu adanya langkah cepat, tepat dan nyata dari pemerintah maupun pelaku usaha untuk menanggulangi kerugian yang telah terjadi akibat pandemi serta melakukan pembaharuan dan evaluasi mengenai siklus usaha mengikuti keadaan yang tengah terjadi agar usaha dapat terus bertahan dan berkembang.

This study aims to determine and analyze the appropriate strategies to improve the economy of MSMEs when new normal is applied due to the impact of the Covid-19 pandemic.. The results obtained from this study indicated that there was a need for fast, precise and tangible steps from the government and business actors to overcome the losses that have occurred due to the pandemic and to make updates and evaluations of the business cycle following the current conditions so that businesses can continue to survive and develop.
\end{abstract}

Keywords : Covid-19, MSMEs, Impact, Strategy

Copyright @ 2020 OECONOMICUS Journal of Economics

\section{Pendahuluan}

Usaha Mikro, Kecil dan Menengah atau UMKM termasuk dalam jenis usaha produktif yang hingga saat ini perkembangannya di Indonesia tergolong sangat pesat. Tercatat hingga saat ini

\section{Editorial Office:}

Prodi Ilmu Ekonomi Fakultas Ekonomi dan Bisnis Islam, UIN Sunan Ampel Surabaya

Jl. Ahmad Yani 117 Surabaya, Jawa Timur 60237, Indonesia.

Email: oje@uinsby.ac.id 
UMKM di Indonesia mencapai 62,9 juta unit yang terdiri dari; pertanian, peternakan, pengolahan, perdagangan, jasa dan komunikasi. Di Indonesia UMKM memiliki peran startegis dan pengaruh yang besar bagi perkembangan ekonomi Nasional dengan jumlah 64.194.057 pada tahun 2018 dengan memperkerjakan sekitar 116.978.631 tenaga kerja (Hardilawati, 2020, p. 90). Kontribusi UMKM terhadap PDB pada tahun 2012 tercatat mencapai angka 59,08\% dan hingga pada tahun 2018 mencapai angka 60\%, total kontribusi tersebut merupakan akumulasi yang berasal dari semua sektor ekonomi UMKM (Kerjasama LPPI dengan Bank Indonesia, 2015, p. 9). Oleh karena itu, dapat dikatakan bahwa UMKM merupakan agen yang mampu membawa perubahan secara terus-menerus pada masyarakat karena mampu membantu memajukan dan membawa inovasi serta meningkatkan kreativitas (Dhewanto et al, 2015, p. 165).

Perkembangan UMKM di Indonesia yang sangat pesat didukung oleh pemanfaatan sarana teknologi, informasi dan komunikasi yang optimal. Namun dibalik itu, terdapat pula faktor yang menjadi penghambat berkembangnya suatu usaha, seperti yang dikemukakan oleh Kuncoro (dalam Setyanto. 2015. p. 207) yang menyatakan tentang faktor penghambat perkembangan suatu usaha secara lebih spesifik, yaitu; Pertama, sulitnya mendapatkan peluang pasar dan memperluas pangsa pasar. Kedua, sulitnya mendapatkan modal karena terbatasnya sumber modal yang memadai. Ketiga, kurangnya pemahaman dalam bidang organisasi dan manajemen SDM. Keempat, Kurang luasnya mitra kerjasama antar pengusaha. Kelima, Persaingan yang tidak sehat antar pengusaha. Keenam, Pembinaan dan pelatihan yang dilakukan masih kurang terpadu dan kurangnya kepedulian serta kepercayaan masyarakat terhadap keberadaan usaha kecil.

Ditengah semakin pesatnya perkembangan UMKM, pergerakannya mengalami penurunan akibat kemunculan Covid-19 pada adal tahun 2020, yang memberikan dampak langsung bagi perputaran perekonomian khususnya bagi UMKM. World Health Organization (WHO) menyatakan bahwa virus yang muncul pertama kali di Kota Wuhan China pada bulan Desember 2019 ini ditetapkan sebagai pandemi. Saat ini pandemi Covid-19 telah menyebar ke seluruh Dunia termasuk Indonesia yang sejak Maret 2020 lalu telah mengonfirmasi kasus positif pertamanya (Tim detiknews, 2020). Coronavirus Disease atau yang biasa disebut dengan Covid-19 termasuk dalam golongan virus yang menjadi penyebab munculnya penyakit pada manusia maupun hewan. Biasanya virus tersebut dapat mengakibatkan munculnya penyakit infeksi yang terjadi pada saluran pernapasan manusia, infeksi paru-paru yang lebih parah seperti MERSCov atau penyakit sindrom akut seperti SARS-Cov bahkan Covid-19 dapat menyebabkan kematian (Tim Kerja Kementerian Dalam Negeri, 2020). Covid19 ditandai dengan munculnya gejala batuk kering, demam, sesak nafas, flu, diare, sakit kepada, mual dan muntah serta nyeri pada otot. Untuk mendeteksi munculnya gejala ditetapkan masa inkubasi virus corona pada tubuh manusia yaitu berkisar antara 2 hingga 14 hari. Tercatat sudah terdapat 216 Negera 
di berbagai belahan dunia yang telah mengonfirmasi kasus positif Covid-19 dengan total keseluruhan mencapai 9.071.475, sedangkan kasus yang tercatat di Indonesia sebanyak 49.009 orang terkonfirmasi positif Covid-19 per tanggal 24 Juni 2020 (Gugus Tugas Percepatan Penanganan Covid-19, 2020).

Dengan bertambahnya kasus positif yang cukup signifikan setiap harinya, maka dikeluarkan Peraturan Pemerintah Nomor 21 Tahun 2020 tentang PSBB atau Pembatasan Sosial Berskala Besar sebagai bagian dari upaya yang dilakukan pemerintah untuk menghentikan rantai penyebaran wabah Covid-19. PSBB diterapkan di berbagai daerah Indonesia dengan masa inkubasi 14 hari dan pemberian sanksi bagi yang melanggar, hal tersebut tertulis pada Pasal 1 Peraturan menteri kesehatan No. 9 Tahun 2020 yang menjelaskan mengenai pembatasan sosial berskala besar pada berbagai wilayah atau daerah yang terdapat kasus positif terinfeksi Covid-19 dengan beberapa kegiatan yang dibatasi seperti ; sekolah, bekerja di kantor, kegamaan, fasilitas umum, sosial budaya, transportasi umum, dan pertahanan keamanan (Detiknews, 2020).

International Monetary Fund (IMF) mecatat bahwa ekonomi global akan berada pada tingkat minus $2 \%$ sebagai akibat dari adanya pandemi Covid-19 yang menjadi wabah di seluruh Dunia yang menyebabkan kontraksi perekonomian Dunia mencapai titik minus, dengan angka sebelum adanya pendemi Covid-19 mencapi 2,9\% (Modjo, 2020, p. 104). Laporan Organisastion for Economic Co-Operation and Development (OECD) mengatakan bahwa virus corona secara aktif terlibat memberikan ancaman krisis ekonomi global yang dapat ditandai dengan pemberhentian aktivitas produksi, menurunnya bursa saham secara signifikan, hingga tingkatekonomi masyarakat yang merosot. OECD memprediksi apabila keadaan ini berlangsung secara terusmenerus, maka akan menyebabkan menurunnya tingkat output di berbagai Negara. Pusat Penelitian Ekonomi LIPI (P2E LIPI) telah memprediksi bahwa salah satu sektor pariwisataa yang paling berdampak yaitu UMKM terutama pada bidang makanan-minuman, sebesar $27 \%$ dan kerajinan, sebesar 17, 03\%. Berdasarkan data dari BPS (Badan Pusat Statistik) PDB ekonomi Indonesia pada triwulan 1 tahun 2020 sebesar $2.97 \%$ yang berarti melambat dibandingkan tahun 2019 triwulan 1 mencapai 5,07, angkat tersebut merupakan pertumuhan yang paling rendah sejak 2001 . Sektor yang paling terpuruk karena adanya Covid-19 adalah UMKM, menyatakan bahwa terdapat sekitar $96 \%$ UMKM yang mengalami dampak negatif pada bisnisnya dan $75 \%$ diantaranya mengalami penurunan terhadap penjualan produknya (Nofianti, 2020). Permasalahan utama yang dihadapi UMKM ialah tidak lain karena turunnya permintaan dari masyarakat atau konsumen secara signifikan.

Dampak dari Covid-19 yang semakin tinggi terutama dalam sektor perekonomian menyebabkan pemerintah memberlakukan kebijakan baru yaitu pelonggaran PSBB menuju kebiasaan baru atau disebut dengan New Normal. Kebiasaan baru yang dimaksud yaitu mengarah pada perubahan terhadap perilaku manusia yang disesuaikan dengan protokol kesehatan dengan tetap 
menjalankan aktivitas normal seperti biasanya. Hal tersebut membuat para pelaku usaha UMKM harus membuat strategi baru untuk tetap bertahan dengan kondisi yang saat ini sedang mengalami penurunan perekonomian. Kebijakan New Normal diharapkan mampu mengembalikan aktivitas bisnis termasuk UMKM, sehingga cepat atau lambat roda perekonomian dapat digerakkan kembali. Namun dalam proses New Normal masyarakat diharapkan mampu beraktifitas kembali di luar rumah dengan tetap mengikuti arahan Pemerintah terkait dengan pandemi Covid-19, hal ini juga berlaku bagi UMKM sehingga dapat menjalankan kembali usahanya yang tentunya dengan strategi baru yang tepat mengikuti kebijakan New Normal. Berdasarkan data dari Kementerian Koperasi dan UKM menyebutkan bahwa terdapat sekitar 163.713 UMKM dan 1.785 koperasi yang terdampak Covid-19 (Novika, 2020)

Pandemi Covid-19 telah membuktikan bahwa UMKM berperan penting terhadap perekonomian Indonesia. Sektor UMKM dinilai paling tinggi tingkat rentannya terhadap pandemi ini karena pada umumnya UMKM berpenghasilan dari perputaran dagangan yang dilakukan setiap hari. Ketika UMKM tidak mampu lagi menopang krisis ekonomi akibat pandemi ini, perekonomian Indonesia turun drastis selain akibat dari industri pariwisata dan manufaktur. Terdapat beberapa strategi atau upaya yang dapat dilakukan oleh pelaku usaha UMKM untuk mengembalikan perekonomiannya, seperti yang diungkapkan oleh Asmini dalam penelitiannya yang mendiskripsikan tentang manajemen Business Cycle yang digunakan untuk dasar mencari peluang usaha pasca pandemic Covid-19 yang kemudian menciptakan strategi pemulihan yang tepat pada perekonomi masyarakat (Asmini et al, 2020, p. 121). Berbeda dengan penelitian yang dilakukan oleh Hardilawati, Hardilawati mengemukakan strategi yang dapat dilakukan oleh UMKM untuk bertahan adalah dengan melakukan perdagangan secara online atau secara ecommerce, mulai melakukan promosi secara digital, serta menjalin dan mengoptimalkan hubungan pemasaran pelanggan. (Hardilawati, 2020, p. 89). Sedangkan menurut Setyano et al (2015. p. 2015) yang telah melakukan penelitian mengenai upaya peningkatan perekonomian UMKM sebelum pandemic Covid-19 menyebutkan bahwa strategi pengembangan UMKM Batik Laweyan dalam meningkatkan perekonomian adalah dengan melakukan inovasi, melakukan pembaharuan produk serta mulai menerapkan modal sosial dengan cara memperluas jaringan bisnis.

Berbeda dengan penelitian yang dilakukan oleh Rukmana dan Sukanta yang menyebutkan mengenai strategi yang dijalankan pada usaha mikro kecil keripik kemasan di kota Bandung agar dapat terus bertahan adalah dengan melakukan pendekatan Lima Kekuatan Persaingan dari Porter. (Rukmana \& Sukanta, 2020, p. 37). Sementara Menurut Prasetyo (2016. p. 150) menyebutkan bahwa strategi yang tepat untuk diterapkan oleh pemilik usaha mikro kecil seperti usaha home industry tempe yang telah menerapkan business model canvas yaitu strategi strength opportunities (SO) atau yang dapat disebut dengan strategi agresif. Penelitian ini memiliki keterkaitan 
dengan penelitin yang dilakukan oleh Fitriyani et al (2020), serta Setiono (2020), Hardilawati (2020) yang membahas mengenai tantangan serta strategi yang dilakukan oleh pelaku UMKM agar dapat mempertahankan bisnisnya.

Berdasarkan latar belakang permasalahan yang telah diuraikan di atas, maka dapat dirumuskan bahwa permasalahan dalam penelitian ini, yaitu 1) Apakah dampak dari diberlakukannya PSBB bagi UMKM? dan 2) Bagaimanakah strategi yang dapat dilakukan oleh UMKM dalam meningkatkan perekonomian akibat pandemi Covid-19 pada saat New Normal?

Adapun maksud dari penelitian ini yaitu untuk menemukan dan melakukan analisis dampak yang diakibatkan dari adanya PSBB selama beberapa bulan terakhir bagi UMKM serta mengetahui strategi yang dapat dilakukan oleh UMKM dalam meningkatkan perekonomian selama pandemi Covid-19 pada saat New Normal. Oleh karena itu, peneliti berharap agar penelitian ini dapat memberikan kontribusi yang bermanfaat dan praktis guna menambah wawasan, menjadi referensi tambahan serta dapat dijadikan sebagai bahan acuan pada penelitian mendatang untuk mengembangkan ilmu pengetahuan khususnya di bidang akuntansi bagi para pelaku usaha UMKM dalam menjalankan bisnisnya di tengah wabah Covid-19.

Penelitian ini dimaksudkan untuk memberikan batasan terhadap studi kualitatif yang dilakukan guna memilih mana data yang tidak relevan dan mana data yang relevan (Moleong, 2013). Pembatasan dalam penelitian ini dibuat berdasarkan pada tingkat urgensi atau kepentingan dengan permasalahan yang dihadapi, yaitu difokuskan pada "Strategi yang dilakukan oleh pelaku usaha (UMKM) dalam mengingkatkan perekonomian selama pandemi Covid-19 dalam masa New Normal.

\section{Kajian Pustaka}

Menurut Hardilawati (2019, p. 91) menjelaskan bahwa pandemi Covid-19 ini akan berdampak secara signifikan terhadap UMKM, hal ini dikarenakan adanya pembatasan operasional usaha dan berkurangnya penjualan serta hilangnya pangsa pasar sebagai akibat dari diberlakukannya PSBB sehingga masyarakat membatasi kegiatan di luar rumah. Pengurangan produksi dilakukan karena daya beli masyarakat turun sebagai akibat dari pendapatan masyarakat yang juga ikut turun dan terutama dikarenakan adanya kebijakan pembatasan sosial yang menyebabkan masyarakat untuk sementara waktu melakukan semua kegiatan dari rumah atau istilah yang dikenal dengan Work From Home, seperti kegiatan belajar, bekerja dan beribadah semuanya dilakukan dari rumah.

\section{Metode Penelitian}

Penelitian ini termasuk ke dalam jenis bagian metode kualitatif deskriptif. Menurut Siyoto dan Sodik (2015, p. 28) menjelaskan bahwa penelitian kualitatif merupakan penelitian yang berkaitan dan berhubungan erat mengenai suatu penafsiran dengan disesuaikan pada fenomena atau peristiwa yang terjadi serta lebih cenderung menggunakan analisis dalam melakukan penelitian. Sedangkan penelitian deskriptif dapat diartikan sebagai keadaan yang 
memaparkan (deskripsi) sebuah kejadian yang mengacu dan menitikberatkan pada permasalahan yang terjadi selama penelitian berlangsung (Noor, 2012, p. 33). Objek yang digunakan yaitu strategi UMKM (Usaha Mikro, Kecil, dan Menengah) selama pandemi Covid-19 pada saat new normal.

Teknik pengumpulan data dilakukan dengan memilih penggunaan studi literatur atau kajian pustaka. Studi literatur adalah bagian dari teknik pengumpulan data yang menekankan pada penelusuran sebuah data historis atau catatan suatu fenomena yang sudah terjadi dan dapat berupa sebuah tulisan-tulisan, bentuk ilustrasi (gambar), artikel, serta susunan sebuah hasil pekerjaan yang berkaitan dengan adanya permasalahan yang diteliti untuk diolah dan dianalisis lebih lanjut (Sugiono, 2012 p. 291). Pengumpulan data pada penelitian ini dapat disajikan dengan mencari literatur seperti; jurnal ilmiah, esai atau artikel, berita, peraturan dan kebijakan mengenai bagaimana strategi UMKM dalam meningkatkan perekonomian selama pandemi Covid-19 pada saat diberlakukannya new normal. Selain itu berkenaan pada data UMKM dapat diperoleh dari website Kemenkop \& UMKM (Kementerian Koperasi dan UMKM) melalui www.depkop.go.id/dataumkm serta website lainya yang membahas mengenai strategi dan dampak UMKM pada saat pandemi Covid-19.

Menurut Bogdan \& Biklen dalam Buku yang ditulis oleh Albi Anggito dan Johan Setiawan (2018, p. 236) menjelaskan bahwa analisis data kualitatif merupakan usaha yang dapat dikerjakan melalui pengorganisasian data dengan mengkategorikan atau mengklasifikasikan temuan untuk menghasilkan keutuhan dan koherensi sebuah data agar bisa dianalisis lebih dalam. Teknik analisis data yaitu pengolahan temuan data yang telah disesuaikan dan diklasifikasikan lalu dianalisis menjadi penjelasan (hasil pembahasan) dalam karya tulis atau sebuah laporan kompleks agar lebih sederhana dan mudah dimengerti. Penelitian ini memilih teknik analisis berupa content analysis (teknik analisis isi), merupakan sebuah teknik yang menjelaskan dan menganalisis secara objektif, sistematik yang disesuaikan dengan penggunaan pendekatan (kualitatif) dalam penelitian yang digunakan (Fraenkel dan Wallen, 2007, p. 483). Krippendorff (2004) mengartikan content analysis merupakan cara atau teknik yang dapat dipilih untuk memperoleh sebuah conclusion dari hasil analisis yang terlebih dahulu telah didapatkan sehingga dapat diterapkan pada berbeda-beda kondisi dan konteks.

Didalam penelitian ini, data-data yang telah ada di analisis berdasakan permasalahan dan topik yang diteliti kemudian membandingkan perolehan data pada fenomena yang berkaitan erat dengan content analysis (Basri, 1998) :

1. Mengumpulkan, menyeleksi temuan data berasal dari kajian pustaka lalu memilahnya menjadi beberapa bagian yang sesuai dengan permasalahan.

2. Mengkategorikan, mengklasifikasikan hasil beberapa seleksi yang telah dipilih secara khusus terutama hal-hal berkenaan pada pembahasan penelitian ini yang telah dikumpulkan lalu diseleksi. 
3. Menganalisa keabsahan data yang telah diklasifikasi dan dikategorikan, kemudian mencoba memadankan bagianbagian persamaan dan perbedaan agar dapat ditemukan hubungan korelasi satu sama lain.

4. Memaparkan hasil analisa dan membuat kesimpulan.

Keabsahan data merupakan bagian penting yang wajib dikerjakan. Keabsahan data dapat dikatakan sebagai pedoman kevalidan data hasil penelitian yang mampu dipertanggung jawabkan kebenarannya, terdapat beberapa jenis yaitu; kredibilitas atau keterpercayaan, realibilitas, objektivitas, dan ketepatan hasil dari penelitan bersangkutan (Moleong, 2006, p. 334). Dalam beberapa sumber buku metodologi penelitian, terdapat beberapa teknik validitas (keabsahan data) yang sering ditemukan, salah satu yang digunakan di sini ialah ketekunan/keajegan pengamatan dan triangulasi sumber data. Keajegan pengamatan maksudnya penyelidikan terhadap proses analisis data yang dilakukan secara berulang dan menginterpretasikan hasil data sesungguhnya, sedangkan ketekunan pengamatan dimaksudkan untuk mengetahui dan mencari setiap unsur dalam berbagai kejadian fenomena yang saat ini sedang ditekuni lalu mengumpulkannya menjadi satu kesatuan secara lengkap dan spesifik (Moleong, 2013, p. 330). Triangulasi sumber data dapat diperoleh apabila memanfaatkan berbagai macam data berdasarkan referensi lainnya untuk menelusuri bukti atau keterangan yang sejenis dan sesuai permasalahan yang diangkat. (Moleong, 2013, p. 330).

\section{Hasil dan Pembahasan}

Dampak Pandemi Covid-19 Bagi UMKM

Sampai saat ini seluruh dunia sedang dihadapkan dengan pandemi Covid 19 yang membuat banyak negara mengalami permasalahan perekonomian yang melemah termasuk perekonomian di indonesia terutama bagi para pelaku Usaha Mikro, Kecil dan Menengah (UMKM). Terhitung dari tanggal 11 Juli 2020 sebanyak 216 negara dengan 12.237.085 jiwa yang terkonfirmasi positif corona, sedangkan yang terjadi di indonesia sudah menyentuh angka diatas lima puluh ribu yaitu sebesar 74.018 jiwa yang terdeteksi positif corona (Gugus Tugas Percepatan Penanganan Covid 19, 2020). Saking cepatnya penularan virus Covid 19 setiap harinya menimbulkan dampak perlambatan perekonomian di Indonesia, salah satunya pelaku usaha UMKM. Perekonomian di indonesia banyak di dominasi oleh UMKM dan mampu menopang perekonomian indonesia, hal ini berdasarkan data yang diperoleh dari Kementerian Koperasi dan Usaha Kecil dan Menengah (KUMKM) mencatat bahwa 99\% adalah pelaku utama penggerak perekonomian indonesia.

Usaha Menengah (60.702 unit) menyerap 3.770 .835 orang atau sekitar $3.13 \%$ tenaga kerja. Sedangkan Usaha Kecil (783.132 unit) menyerap 5.831.256 orang atau sekitar $4.84 \%$ tenaga kerja dan Usaha Mikro (63.350.222 unit) mampu menyerap setidaknya 107.376 .540 atau sekitar $89.04 \%$ tenaga kerja (Kementerian Koperasi Usaha Kecil dan Menengah, 2018). Membuktikan bahwa UMKM merupakan titik tumpu perekonomian Indonesia, dengan adanya 
pandemi seperti ini UMKM mengalami kesulitan saat memasarkan produknya. Menurut Safiah et al (2019) UMKM adalah penggerak utama perekonomian di Indonesia karena mampu menyediakan lapangan pekerjaan baru dalam jumlah yang sangat besar, hal inilah yang menjadikannya penggerak utama roda perekonomian lokal dan pemberdayaan masyarakat. Pemerintah akhirnya mengeluarkan sebuah kebijakan agar memutus mata rantai penyebaran covid19 dengan cara menetapkan Pembatasan Sosial Berskala Besar (PSBB dengan melakukan physical distancing yang merupakan tindakan agar mampu mencegah penularan Covid 19 terhadap satu sama lain. PSBB memberikan dampak negatif bagi UMKM, dikarenakan UMKM bersifat harian yang harus mengandalkan interaksi secara langsung terhadap konsumen (CNBC, 2020). Sehingga diberlakukannya PSBB membuat UMKM kurang maksimal dalam memasarkan produknya, bahkan permintaan konsumen cenderung menurun setiap harinya akibat PSBB. Dampak yang ditimbulkan antara lain:

Pertama, penjualan menurun drastis akibat adanya PSBB yang diterapkan untuk mencegah penyebaran virus Covid-19. Pada situasi ini terdapat sekitar 37.000 UMKM melapor pada hotline call center Kemenkop UMKM yang terdampak adanya pandemi ini, $56 \%$ dari pelaku usaha UMKM mengeluhkan penurunan penjualan yang signifikan, penjualan UMKM yang menurun diikuti dengan adanya pemberlakuan PSBB selama beberapa bulan terakhir (Pakpahan, 2020, p. 92). Masyarakat diharuskan bekerja, beribadah, dan belajar dari rumah menyebabkan terjadinya perubahan perilaku konsumsi masyarakat. Aktivitas UMKM yang setiap harinya bersinggungan langsung dengan konsumen untuk menawarkan produknya menjadi berkurang dikarenakan masyarakat diharuskan tetap berada di rumah untuk mematuhi protokol kesehatan. Pergeseran pola konsumsi masyarakat menyebabkan turunnya penjualan, saat ini masyarakat lebih memilih untuk memprioritaskan kebutuhan pada makanan dan yang berkaitan dengan alat kesehatan daripada membeli kebutuhan lainnya yang dinilai kurang penting dan bukan merupakan kebutuhan utama untuk menghadapi kondisi saat ini.

Kedua, Strategi Pemasaran pada UMKM terbilang sulit pada kondisi pandemi saat ini. Karena ditengah wabah pandemi Covid-19 UMKM dituntut untuk mengganti strategi pemasarannya dari offline menjadi online agar tetap dapat mempertahankan perekonomiannya. Sampai saat ini UMKM berhasil mempertahankan usahanya walaupun situasi yang terjadi, terlebih lagi pada saat kondisi ekonomi tahun 1998 UMKM mampu menunjukkan eksistensinya menjadi penyangga dengan memberikan kenaikan nilai ekspor hingga $350 \%$ (Nurhaliza, 2020). Pada saat itu Indonesia diuntungkan dengan kondisi ekonomi global yang bagus, namun berbeda kondisi dengan yang terjadi saat ini ekonomi global sedang melemah dikarenakan pandemi Covid-19. Seperti yang terjadi pada UMKM pada sektor non-kuliner mengalami penurunan signifikan sebesar $35 \%$ sejak mulai muculnya wabah pandemi Covid-19 ini (Bahtiar \& Saragih, 2020, p. 21). Hal tersebut disebabkan oleh penjualan produk tersebut bertumpu pada tatap muka secara 
langsung kepada konsumen atau secara offline, sehingga ketika kebijakan PSBB diberlakukan UMKM mengalami kendala dalam hal pemasaran. Selama pandemi Covid-19 kegiatan pemasaran tidak dapat berjalan dengan baik karena pangsa pasar yang sepi dan berkurang akibat aturan PSBB di berbagai wilayah di Indonesia, sehingga para pelaku usaha UMKM harus menutup tokonya bahkan sampai merumahkan sebagian karyawannya (Tim Yanmas DPKM UGM, 2020). Pandemi Covid-19 mengakibatkankan adanya pergesaran dan perubahan pola pembelian konsumen, meskipun beberapa pelaku usaha UMKM juga menyediakan secara online namun tidak menutup kemungkinan bahwa masih banyak konsumen yang lebih senang berbelanja secara offline (Hardilawati, 2020, p. 91). Sehingga karena adanya pembatasan sosial maka masyarakat cenderung mengurangi aktivitas diluaran rumah, pelaku UMKM yang memperdagangkan produknya secara offline harus ikut merasakan dampak akibat pemasarannya berkurang.

Ketiga, pendanaan atau permodalan. Selama pandemi Covid-19 UMKM mengalami kendala berupa permodalan, hal tersebut dikarenakan kredit usaha yang diambil pelaku UMKM mengalami kemacetan sehingga dibutuhkan suntikan dan bantuan terkait permodalan (Tim Yanmas DPKM UGM, 2020). UMKM mengalami penurunan kinerja dari sisi permintaan sehingga dampak yang terjadi adalah pemutusan hubungan kerja dan juga kemacetan pembayaran kredit semenjak terjadinya wabah Covid 19 (Pakpahan, 2020, p. 20). Terganggunya kegiatan ekonomi akibat pandemi Covid-19 sangat mempengaruhi pelaku usaha UMKM yang mempunyai pendanaan atau permodalan yang kecil atau terbatas. Bantuan modal diperlukan agar pelaku usaha mampu mengatasi kesulitan yang dihadapinya selama pandemi Covid-19 berlangsung.

Keempat, pandemi Covid-19 berdampak pada kegiatan produksi dan distribusi pelaku usaha UMKM mengalami penurunan dan bahkan sampai menghentikan kegiatan produksinya selama beberapa waktu (Pakpahan, 2020). Selama beberapa bulan terjadi pandemi Covid-19, $70 \%$ UMKM menyatakan telah menghentikan proses produksinya dan $90 \%$ pelaku usaha UMKM mengatakan bahwa cashflow mereka terdampak (Hamdani, 2020). Hal tersebut sesuai dengan survei yang telah dilakukan oleh Organisasi Buruh International (ILO) Indonesia bersama dengan konstituen dan mitra pelaksana terhadap 571 perusahaan yang terdampak Covid-19 pada April 2020 lalu. Penghentian proses produksi tersebut dapat bersifat sementara atau bersifat permanen. Pelaku usaha UMKM menghentikan proses produksinya dikarenakan permintaan pasar mengalami penurunan drastis semenjak Covid-19 mulai memasuki daerah teritori indonesia, sementara itu sebanyak $26.7 \%$ UMKM yang bertahan meski harus menghentikan proses produksinya untuk sementara waktu ini (Hamdani, 2020). Bahkan UMKM akan membatasi produksinya dengan jumlah yang lebih kecil daripada sebelum terjadinya pandemi Covid-19. Terlebih lagi adanya Pembatasan Sosial Berskala Besar (PSBB) waktu lalu membuat proses pengiriman menjadi terhambat. 
Kelima, kesulitan dalam memperoleh bahan baku. Sejak pandemi Covid-19 berlangsung bahan baku yang dibutuhkan oleh pelaku usaha UMKM mengalami kesulitan dalam memperolehnya. Hal tersebut disebabkan melambatnya impor salah satunya pada bahan pangan bukan karena Rekomendasi Impor Produk Hortikultura (RIPH), tetapi melainkan karena wabah Covid-19 (Santia, 2020). Bahkan sebelum adanya pandemi Covid-19 saat ini, permasalahan UMKM juga tidak terlepas dari adanya keterbatasan akses terhadap bahan baku, sehingga banyak dari pelaku usaha UMKM memperoleh bahan baku dengan kualitas yang rendah (Tim LPPI \& Bank Indonesia, 2015, p. 20). UMKM mempunyai peran yang strategis dalam membangun ekonomi bangsa, meskipun dalam kondisi pandemi Covid-19 saat ini UMKM harus mampu menunjukkan dan mempertahankan eksistensinya untuk tetap dapat membantu memulihkan perekonomian Indonesia ditengah wabah pandemi. Namun ada sektor pelaku usaha UMKM yang mampu meningkatkan eksistensinya di tengah pandemi Covid-19, seperti produk kesehatan yang mampu naik sebesar 90\%, produk yang berhubungan dengan hobi outdor dan indoor juga mampu naik hingga $60 \%$ serta produk makanan herbal yang juga mengalami kenaikan (CNBC, 2020). Selain itu UMKM yang bergerak dalam bidang logistik, industri laundry mampu meningkatkan penjualannya di tengah wabah pandemi Covid-19 (Evandio, 2020). Maka dari itu, perhatian pemerintah terhadap pelaku usaha UMKM yang terdampak Covid-19 perlu ditingkatkan sehingga dapat dilakukan upaya strategis untuk mempertahankan dan memulihkan perekonomian Indonesia agar tidak terpuruk dalam kondisi pandemi Covid-19 yang melanda Dunia saat ini.

Strategi yang Dapat dilakukan UMKM dalam Meningkatkan Perekonomian Akibat Pandemi Covid-19 Pada Saat New Normal. Krisis yang diakibatkan oleh virus corona yang terjadi saat ini tidaklah sama dengan krisis keuangan yang pernah menimpa Indonesia sebelumnya. Krisis keuangan membuat daya beli turun secara signifikan, namun krisis akibat pandemi Covid-19 karena masyarakat menahan daya beli akibat kebijakan terkait dengan PSBB guna keselamatan bersama. UMKM juga merasa terpukul akibat kebijakan yang dikeluarkan oleh pemerintah agar menghimbau para masyarakat untuk ditiadakannya mudik/pulang kampung dahulu karena dampak yang dialami oleh UMKM sangat lah besar sampai banyak diantaranya memutuskan untuk menutup usaha tersebut. Seperti pedagang warung makan di jalan jalur mudik, perhotelan, pedagang oleh-oleh khas suatu daerah, hingga tukang tambal ban pun turut merasakan. Keluhan yang banyak dirasakan bagi para pelaku UMKM pada umumnya adalah penjualan yang menurun, susah untuk memperoleh bahan baku, serta distribusi yang terhambat. Akibat dari penurunan ekonomi ini, hampir setiap negara perlahan-lahan menerapkan new normal untuk mendorong kembali roda perekonomian, tidak terkecuali dengan Indonesia. (Arif, 2020).

Dalam rangka memulihkan dan menata kembali kondisi ekonomi Indonesia yang terus melemah akibat Covid-10 ini diperlukan strategi dan jalan keluar yang 
tepat mengingat banyaknya kerugian dan semakin ketatnya persaingan antar pengusaha sehingga harus selalu melakukan pembaharuan dan evaluasi mengenai siklus usaha mengikuti keadaan yang tengah terjadi agar usaha dapat terus bertahan dan berkembang. Terdapat berbagai cara yang dapat dilakukan oleh pelaku usaha khususnya UMKM menghadapi kebijakan pemerintah mengenai new normal. Menurut Asmini et al (2020) ada tujuh faktor penting yang perlu diperhatikan oleh sebuah perusahaan agar dapat tumbuh dan mengembangkan usahanya dalam jangka waktu lama, yaitu; 1. Kesatuan Visi dan Misi (Strategic Intent), 2. Pengambilan keputusan yang cepat dan tepat (Desicion Maker), 3. Manajemen keuangan terencana (Funding), 4. Perencanaan bisnis, 5. Manajemen TIM, 6. Eksekusi, 7. Saat yang tepat untuk memulai usaha. Selain hal tersebut diperlukan pula perencanaan ulang serta menyiapkan rencana cadangan sebagai upaya mengantisipasi berbagai kemungkinan yang mungkin terjadi akibat pandemi yang tidak dapat diperkirakan. Menghadapi hal ini, pemerintah mengeluarkan kebijakan yaitu diantaranya Pemerintah akan menanggung pajak penghasilan pekerja atau $\mathrm{PPh} 21$ di sektor industri pengolahan dengan penghasilan maksimal Rp. 200 juta dalam satu tahun, membebaskan PPh impor untuk 19 sektor tertentu. Kebijakan ini diarahkan untuk Wajib Pajak Kemudahan Impor Tujuan Ekspor (KITE) serta Wajib Pajak KITE Industri Kecil dan Wajib Pajak KITE Industri Kecil Menengah. Selain itu, tarif PPh badan diturunkan menjadi 22\% untuk tahun 2020 dan 2021 serta menjadi 20\% mulai tahun 2022. Tidak sedikit pula usaha yang tidak mengalami penurunan penghasilan seperti e-commerce, dan digital marketing. Pelaku bisnis UMKM juga dapat mengikuti dan memanfaatkan teknologi untuk meningkatkan pemasaran usaha, seperti memanfaat media sosial facebook ads, instagram ads dan berbagai platform sosial lainnya serta memberikan pelayanan delivery.

Pemerintah juga menyiapkan deretan insentif agar usaha UMKM dapat terus bertahan di masa pandemi ini. Selain itu, pemerintah juga menekankan stimulus ekonomi harus menjangkau semua pelaku usaha kecil mikro menengah (UMKM) serta informal seperti pedagang kaki lima (PKL). Menurut Peneliti INDEF, stimulus yang dikucurkan oleh pemerintah seharusnya juga membuat pelaku UMKM bisa terus hidup, tidak hanya mengurangi beban biaya UMKM saja. Seperti contoh di Semarang, Jawa Tengah, pelaku usaha pengolahan bandeng duri lunak mengakui bahwa omset mereka turun hingga 90\%. Untuk menanggulangi agar usahanya tidak gulung tikar, maka mereka mengurangi jumlah produksi. Hal yang sama juga dialami oleh pelaku usaha sektor pangan, dimana salah satu warteg di Tanjung Duren mengaku mengalami penurunan omset hingga $70 \%$ akibat pandemi corona. Selain itu dampak yang diakibatkan oleh pandemi Covid-19 ini juga telah dipaparkan diatas. Perlu langkah yang cepat, tepat, dan nyata untuk menyelamatkan perekonomian dari pandemi corona. Apalagi UMKM tidak hanya dipandang sebagai alternatif, namun sebagai tulang punggung atau pondasi ekonomi negara. Untuk tetap mempertahankan 
usahanya, para pelaku sebaiknya tidak hanya mengandalakan bantuan dari pemerintah namun mereka juga harus memiliki strategi sendiri agar usaha mereka tetap berjalan ditengah pandemi Covid-19 ini dan yang pasti sesuai dengan kebijakan pemerintah mengenai adanya new normal.

Karena adanya ketetapan pemerintah yang menuntut masyarakat agar bekerja, beribadah, dan belajar dari rumah menjadikan perubahan perilaku konsumsi masyarakat, di masa sekarang pengaplikasian teknologi bisa menjadi solusi terbaik bagi para UMKM untuk tetap menjalankan roda perokonomian. Menurut Standie dikutip dari Kontan.co.id "Selain bantuan modal, pemasaran melalui daring dan automasi pembukuan akan memudahkan UKM dalam menyusun strategi yang sekiranya tepat guna kelangsungan usaha untuk saat ini dan kedepannya". Ditengah himbauan adanya social distancing atau menejaga jarak satu sama lain, media sosial bisa menjadi salah satu cara untuk mempromosikan usaha yang dimiliki. (Hutauruk, 2020). Kesehatan cashflow juga tidak kalah penting. Saat ini, telah banyak bermunculan aplikasi-aplikasi yang dapat membantu penjurnalan secara online dan simpel. Hal ini bisa di manfaatkan oleh pelaku UMKM untuk mengontrol arus kas dari usaha mereka.

Para pelaku UMKM harus tetap fokus pada kebutuhan konsumen dan selalu berinovasi sesuai perubahan preferensi dan perilaku konsumen (Kiryanto, Kepala Ekonomi PT BNI). Banyak pelaku usaha yang kesulitan dalam mengelola bisnisnya bahkan tidak selamat di tengah pandemi yang sedang berlangsung hingga saat ini.
Perlu disiapkan strategi-strategi baru dalam menghadapi bahkan setelah pandemi mereda. Tetap menjaga hubungan baik dengan supplier, distributor dan vendor, dan juga bekerja sama dengan dengan lembaga keuangan seperti perbankan sebagai mitra sebagai sumber pembiayaan dan pendampingan pengembangan usaha merupakan hal yang harus dilakukan oleh para pelaku usaha. UMKM harus bisa menjaga ketersediaan dana untuk pelunasan kewajiban.

Khusus bagi UMKM dan sektor terdampak, pemerintah sudah mengeluarkan Kebijakan Peraturan Otoritas Jasa Keuangan No. 11/POJK.03/2020 tentang Stimulus Perekonomian Nasional sebagai Kebijakan Countercyclical Dampak Penyebaran Corona Virus Disease 19. Mengenai restrukturisasi pembiayaan/kredit yang dilakukan yakni dengan memberikan perlakuan khusus terhadap kredit atau pembiayaan bank dengan jumlah tertentu berupa keringanan pembayaran angsuran melalui program restrukturisasi pembiayaan leasing dengan jangka waktu 1 tahun. Restrukturisasi dilakukan dengan sebagaimana diatur dalam POJK mengenaik penilaian kualitas aset, antara lain menurunkan suku bunga, pengurangan tunggakan bunga, pengurangan tunggakan pokok, perpanjangan jangka waktu, penambahan fasilitas pembiayaan/kredit dan atau konversi pembiayaan/kredit menjadi penyertaan modal sementara. (Tim Redaksi BJ, 2020).

Melihat semakin menurunnya pendapatan yang diterima oleh pemilik UMKM menyebabkan modal yang dimiliki untuk meanjutkan usaha juga ikut menyusut, 
terdapat 3 hal yang perlu diperhatikan untuk memperbaiki dan memperkuat kondisi UMKM yaitu finansial, peningkatan sumber daya manusia dan inovasi model pemasaran terkini. Dalam hal finansial, pemilik usaha harus memisahkan keuangan yang dapat diputar untuk menjadi modal dan tidak serta mempertimbangkan produk yang perlu diproduksi dan tidak untuk mengurangi biaya produksi, apabila dibutuhkan hanya melakuan produksi setelah dilakukan pemesanan oleh pelanggan. Direktur Utama BRI, Sunarso dalam Webinar CORE Economic Forum 2020 memaparkan peran dan langkah yang diambil BRI dalam upaya penyelamatan UMKM di Indonesia yaitu dengan menyalurkan kredit dalam rangka penempatan dana mencapai Rp.13,59 triliun. (Ramdhani, 2020). Menteri Koperasi dan UKM Teten Masduki menjelaskan bahwa saat ini pemerintah telah mengeluarkan langkah strategis untuk memberikan bantuan guna membangkitkan kembali UMKM dalam krisis ekonomi ini. Berikut kebijakan skema pemulihan dan perlingan UMKM yang dibuat oleh Pemerintah, yaitu Memberikan bantuan sosial dan insentif pajak bagi UMKM dengan omset kurang dari Rp.4,8 miliar per tahun, memberikan restrukturisasi dan relaksasi kredit bagi UMKM, perluasan pembiayaan modal kerja UMKM, serta pemerintah mengimbau agat Kementerian, BUMN dan pemerintah daerah harus menyadi penyangga bagi produk UMKM. Oleh karena itu, pemetaan para pelaku UMKM dibutuhkan agar program pemerintah dapat terlaksana secara tepat sasaran, tepat guna dan efektif sehingga dapat mempercepat pemulihan ekonomi.
Hampir seluruh pelaku UMKM terpukul akibat adanya pandemi ini. Namun, di tengah penyebaran virus corona saat ini, para pelaku usaha harus dapat melakukan berbagai strategi agar bisnis yang mereka jalankan tetap bertahan. Leonard Theosabrata, Direktur Utama SMESCO, Kementrian Koperasi dan UKM Indonesia memberi beberapa langkah antisipasi terhadap fenomena yang berdampak pada performa bisnis UKM. Dalam survival mode ini yang menjadi pesan utama adalah mengutamakan berjalannya cash flow bisnis dengan baik, dibanding memikirkan profit. Perlu dilakukan perubahan metode bisnis sementara agar laporan keuangan tetap positif. Strategi yang dapat dilakukan yakni dengan menelaah kembali bisnis, permudah prosesnya, kenali customer base serta kebutuhannya, klasifikasi produk yang mudah dijual. Dan juga hal yang tidak boleh dilewati adalah segera lakukan digitalisasi produk dengan mengunggahnya ke dalam katalog yang mudah dibagikan. Ada beberapa langkah praktikal yang bisa dilakukan pelaku usaha agar laporan keuangan tetap positif. Pertama, fokus pada promosi untuk take-away delivery, karena permintaannya saat ini yang cenderung meningkat. Untuk kunjungan fisik, usahakan untuk melakukan transaksi nontunai dengan menggunakan digital payment atau debit. Kedua, meningkatkan kepercayaan konsumen dengan memposisikan diri sebagai bisnis yang memperhatikan total quality management terhadap konsumen dan seluruh stakeholder bisnis terkait higienitas. Turut serta dalam pencegahan penyebaran virus dan juga tetap menjaga kenyamanan konsumen dengan 
penggunaan masker, hand sanitizer, dan pentingnya untuk terus menjaga kebersihan di lingkungan sekitar. (Andriani, 2020)

Rukmana \& Sukanta mengemukakan dalam penelitiannya bahwa pelaku usaha UMKM dapat memilih dua alternatif pilihan untuk menghindari terjadinya penghentian kegiatan produksi, yaitu menaikkan harga jual produk dengan tetap mempertahankan kualitas atau tidak menaikkan harga produk dengan catatan kualitas produk yang diberikan menurun dari yang sebelumnya. Hal ini juga terkait dengan ketersediaan bahan baku pada produk tertentu yang kian langka akibat tingginya permintaan terhadap produk tertentu, maka pengusaha harus berani mengambil risiko untuk memilih dua pilihan tersebut. Solusi lain yang dapat dilakukan oleh para pelaku UMKM yaitu: pertama perlu memiliki manajemen yang terintegrasi mengenai stok produk guna memantau persediaan barang, kedua memantau pengiriman barang dagangan baik di dalam maupun di luar kota, ketiga mengupayakan komunikasi yang cepat kepada pelanggan sekalipun melalui media sosial, keempat mengusahakan menggunakan sistem pembayaran melalui transfer bank maupun pembayaran elektronik. (Arif, 2020).

\section{Kesimpulan}

1. Pandemi Covid-19 memberikan dampak begitu besar bagi UMKM khususnya saat adanya kebijakan PSBB. Penjualan yang menurun drastis, sulit memasarkan produk, terjadi masalah pada pendanaan atau permodalan, kegiatan produksi dan distribusi mengalami penurunan, serta kesulitan mendapat bahan baku merupakan dampak yang di alami oleh pelaku usaha.

2. Strategi yang dapat dilakukan oleh pelaku usaha antara lain melayani konsumen melalui platform online, meningkatkan total quality management terkait higienitas, serta perubahan metode bisnis sementara agar laporan keuangan tetap positif. Selain itu pemerintah memberikan bantuan sosial dan insentif pajak, restrukturisasi dan relaksasi kredit, serta perluasan pembiayaan modal bagi UMKM.

\section{Daftar Pustaka}

Badan Pusat Statistik. (2020). Ekonomi Indonesia Triwulan I 2020 Tumbuh 2,97\%. Diambil kembali dari https://www.bps.go.id

Andriani, D. (2020, Maret 20). Ini Strategi UMKM Bertahan di Tengah Pandemi Virus Corona. Retrieved from Bisnis.com: https://m.bisnis.com/amp/

Andriani, D. (2020, Maret 20). Ini Strategi UMKM Bertahan di Tengah Pandemi Virus Corona. Diambil kembali dari Bisnis.com: https://m.bicnic.com/amp/

Anggito, A., \& Setiawan, J. (2018). Metodologi Penelitian Kualitatif. Sukabumi: CV Jejak.

Arif, N. (2020). Strategi UMKM Dalam Menghadapi New Normal . Dipetik 2020, dari Suara.com: https://www.suara.com/yoursay/strateg i-umkm-dalam-menghadapi-newnormal

Asmini, Sutama, I. N., Haryadi, W., \& Rachman, R. (2020). Manajemen Business Cycle Sebagai Basis Peluang 
Usaha Pasca Covid-19: suatu Strategi Pemulihan Ekonomi Masyarakat. Indonesian Journal of Social Sciences and Humanities, 1(2), 121-129.

Bachtiar, R., \& P.S, J. (2020). Dampak Covid-19 Terhadap Perlambatan Ekonomi Sektor UMKM. 12, 19-24.

Basri, C. H. (1998). Penuntun Penyusunan Rencana Penelitian dan Penulisan Skripsi . Bandung: Logos.

CNBC. (2020, April 29). Ini Kata Teten Masduki Soal Dampak Covid-19 Bagi UMKM. Dipetik 2020, dari CNBC Indonesia:

https://www.cnbcindonesia.com/news/

Evandio, A. (2020, Maret 19). Ini Sektor UMKM yang Meroket dan Tertekan Selama Pandemi Covid-19. Diambil kembali dari Bisnis.com: https://www.google.com/amp/s/m.bisni s.com

Faizah, H. N., \& M, S. (2019). UMKM Dalam Persaingan Di Era Globalisasi Ekonomi, 3(2). Diambil kembali dari https://jurnal.ustjogja.ac.id

Fitriyani, I., Sudiyarti, N., \& Fietroh, M. (2020, Mei). Strategi Manajemen Bisnis Pasca Pandemi Covid-19. Indonesian Journal of Social Sciences and Humanities, 1(2), 87-95.

Frankel, J., \& Wallen, N. (2008). How to Design and Evaluate Research in Education. New York: McGraw-Hill Companies, Inc.

Gugus Tugas Percepatan Penanganan Covid-19. (2020). Data Sebaran. Diambil kembali dari https://covid19.go.id

Hamdani, T. (2020, Mei 3). 70\% UMKM Mati Suri Gara-gara Dihantam Corona . Diambil kembali dari DetikFinance: https://m.liputan6.com/

Hardilawati, W. L. (2020, Juni). Strategi Bertaan UMKM di Tengah Pandemi Covid-19. Jurnal Akuntansi \& Ekonomika, 10(1), 90-98.

Hardilawati, W. L. (2020, Juni 1). Strategi Bertahan UMKM di Tengah Pandemi Covid-19. Jurnal Akuntansi \& Ekonomika, 10(1), 90-98.

Hutauruk, M. (2020, Maret 30). Tips Agar Pelaku UMKM Bisa Bertahan Hadapi Krisis Akibat Pandemi Virus Corona. Retrieved from Kontan.co.id: hrrps://personalfinance.kontan.co.id/ne ws/

Kementerian Koperasi dan Usaha Kecil dan Menengah. (2018). Perkembangan Data Usaha Mikro Kecil Menengah (UMKM) dan Usaha Besar (UB) Tahun 2017-2018. Diambil kembali dari https://www.depkop.gp.id/data-umkm

Kerjasama LPPI dengan Bank Indonesia. (2015). Profil Bisnis Usaha Mikro, Kecil dan Mengengah (UMKM) (PBI No.17/12/PBI/2015). Retrieved from https://www.bi.go.id/

Krippendorff, K. (2004). Content Analysis : an Introduction to its Methodology. New York: Sage Publication.

Modjo, M. (2020). Memetakan Jalan Penguatan Ekonomi Pasca Pandemi. The Indonesian Journal of Development Planning, 4, 103-116. 
Moleong, L. J. (2013). Metode Penelitian Kualitatif. (edisi revisi ed.). Bandung: PT. Remaja Rosdakarya.

Moleong.J.L. (2006). Metodologi Penelitian Kualitatif. Bandung: Remaja Rosdakarya.

Nofianti, L. (2020). Solusi UMKM di New Normal. Dipetik Juni 24, 2020, dari https://uinsuska.ac.id/2020/06/16/solusi-umkmdi-new-normal/

Noor, J. (2012). Metode Penelitian. Jakarta: Kencana.

Novika, S. (2020, Mei 28). Bakal Ada New Normal, UMKM: Manimak Goyangan Ekonomi Muncul. Diambil kembali dari Detik Finance: https://m.detik.com/

Nurhaliza.S. (2020, Mei 15). UMKM Terdampak Covid-19, Menteri Taten: Tentu Beda dari Krisis Keuangan 1998. Diambil kembali dari IDX Xhannel: https://www.idxchannel.com

Nurhidayat, L. T. (2020). Pengaruh Covid19 Terhadap Pertumbuhan UMKM di Indonesia. Dipetik Juni 28, 2020, dari Sukabumi Update.com: https://amp.sukabumiupdate.com/detail /bale-warga/opini/67200-Pengaruh-

Covid-19-Terhadap-PertumbuhanUMKM-di-Indonesia

Pakpahan, A. (2020). Covid-19 dan Implikasi Bagi Usaha Mikro, Kecil dan Menengah. Jurnal Ilmiah Hubungan Internasional, 56-64.

Permana, H. S. (2017). Strategi Peningkatan Usaha Mikro, Kecil dan Menengah (UMKM) Di Indonesia, 8 (1). Diambil kembali dari https://jurnal.dpr.go.id

Prasetyo, D. (2016). Penerapan Business Model Canvas untuk Menciptakan Alternatif Strategi Bisnis di Dalam Pengembangan Kegiatan Usaha Mikro Kecil dan Menengah Tahun 2015 (Studi Pada UMKM Home Industry tempe di Kota Bandar Lampung). Skripsi, Universitas Lampung, Fakultas Ilmu Sosial dan ILmu Politik, Bandar Lampung.

Putra, M. (2020, April 26). Arti PSBB dan 7 Kegiatan yang Dibatasi. Diambil kembali dari Detiknews: https://m.detik.com/news

Ramdhani, G. (2020, Juli 16). Dukung UMKM Maju, BRI Salurkan Kredir Rp.13,59 Triliun dan Bangun Ekosistem Bisnis. Dipetik Juli 18, 2020, dari Liputan 6: https://m.liputan6.com/bisnis/read/430 6580/dukung-umkm-maju-brisalurkan-kredit-rp-1359-triliun-danbangun-ekosistembisnis?medium=dable_mobile\&campai gn=related_click_4

Rukmana, A. Y., \& Sukanta, T. A. (2020, Mei 1). Analisis Strategi Bersaing dan Strategi Bertahan pada Industri Mikro dan Kecil Panganan Keripik Kemasan di Kecamatan Coblong Kota Bandung Jawa Barat Tahun 2020 Ditengah Situasi Sulit Penyebaran Pandemi COVID-19. Jurnal Sains Manajemen \& Akuntansi, 12(1), 37-53.

Safriah, S. N., Atmaja, H. E., \& Verawati, M. (2019). UMKM Sebagai Pilar Membangun Ekonomi Bangsa, 4(2). 
Diambil kembali dari https://jurnal.untidar.ac.id

Santia, T. (2020, Maret 19). Wabah Corona Bikin Impor Pangan Terhambat. Diambil kembali dari Liputan 6: https://m.liputan6.com/

Setyanto, A. R., Samodra, N. R., \& Pratama, Y. P. (2015, Oktober). Kajian Strategi Pemberdayaan UMKM dalam Menghadapi Perdagangan Bebas Kawasan ASEAN (Studi Kasus Kampung Batik Laweyan). Etikonomi, 14(2), 205-220.

Siyoto, S., \& Ali, S. (2015). Dasar Metodologi Penelitian. Yogyakarta: Literasi Media Publishing.

Sugiyono. (2012). Memahami Penelitian Kualitatif. Bandung: Alfabeta.

Tim Detik News. (2020, April 26). Kapan Sebenarnya Corona Masuk RI? Diambil kembali dari Detiknews: https://m.detik.com/news

Tim Kerja Kementerian Dalam Negeri. (2020). Pedoman Umum Menghadapi Pandemi Covid-19. Diambil kembali dari Kemendagri: https://www.kemendagri.go.id

Tim Redaksi BJ. (2020, Mei 05). Begini Strategi UMKM Bertahan di Tengah Pandemi Covid-19. Retrieved from Bisnis Jakarta: http://bisnisjakarta.co.id Tim Yanmas DPKM UGM. (2020, Mei). Dampak Awal Pandemi Covid-19 Terhadap UMKM. Diambil kembali dari Direktorat Pengabdian Kepada Masyarakat:https://pengabdian.ugm.ac. id/dampak-awal-pandemi-covid-19-
Vience Mutiara Rumata. (2017). Analisis Isi Kualitatif Twitter "\#TaxAmnesty" dan "\#Amnesti Pajak". Jurnal PIKOM, 18(1). 